\title{
CENA MITOPOÉTICA: RELAÇÕES DO CONSCIENTE E DO INCONSCIENTE NO PROCESSO DE CRIAÇÃO
}

\author{
Autores: Saulo Vinícius Almeida \\ Luciana Morteo Éboli \\ UFRGS
}

\begin{abstract}
Resumo:
Este trabalho analisa o conceito de Mitopoética no espetáculo Sebastian, uma obra de dança teatro que se constitui a partir do encontro do mito de São Sebastião com a história do ator-dançarino Sebastian Habib. Com base nos estudos do mito de Mircea Eliade e do rito por Michel Mauss, discute as escolhas cênicas e o processo de criação a partir do conceito de mito pessoal. Relaciona conceitos simbólicos de Carl Jung, elementos das memórias individual e coletiva, além das narrativas expressas através da memória do corpo, nas percepções de Gaston Bachelard, Jerzy Grotowski e Antonin Artaud.
\end{abstract}

Palavras-chave: Mitopoética. Rito. Processo de criação. Encenação.

\section{Abstract:}

This article analyzes the Mythopoetic concept applied to the spectacle Sebastian, a work of dance theater that is constituted from the meeting of the myth of San Sebastián with the history of the actor-dancer Sebastian Habib. Based on the studies of the myth of Mircea Eliade and the rite by Michel Mauss, we discuss the scenic choices and the process of creation from the concept of personal myth. It relates Carl Jung's symbolic concepts, elements of individual and collective memories, and the narratives expressed through the memory of the body, through the perceptions of Gaston Bachelard, Jerzy Grotowski, and Antonin Artaud.

Keywords: Mythopoetic. Rite. Creation process. Staging.

\section{O espetáculo e sua origem}

O espetáculo Sebastian é uma obra de dança teatro que se constitui a partir do encontro do mito de São Sebastião com a história do ator-dançarino Sebastian Habib. Ainda que o processo de criação do espetáculo tenha como origem a narrativa mítica, torna-se difícil especificar o seu ponto de partida, pois esse processo está intimamente ligado à história de vida do performer.

O mito em questão atravessou de diversas maneiras da vida de Sebastian Habib e também constituiu sua identidade, pois o compreendendo como um dos 
constituintes de sua mitologia pessoal, ele abarcaria questões identitárias, assim como de direcionamento e propósito da vida (FEINSTEIN \& KRIPPNER, 1997). Desse modo, o espetáculo teve sua gestação iniciada muito antes que os artistas envolvidos tivessem consciência de sua existência. Nossa compreensão de mitopoética extrapola a ofertada pelo dicionário que a compreende como origem e criação de mitos e vai de encontro a ampliação proposta por Walter Boechat (2008) que a entende como a capacidade natural e espontânea da psique de produzir imagens mitológicas que operando por uma via simbólica possui a função de solucionar os opostos consciente e inconsciente.

O mito pessoal, segundo os autores David Feinstein e Stanley Krippner (1997), atua como uma lente que modifica a percepção que o indivíduo possui de si e do mundo, partindo para tanto de uma constelação de crenças, sentimentos e imagens organizadas em torno de um tema central.

No âmago de um mito pessoal encontra-se um tema central. Você organiza novas experiências em torno desses temas. O tema serve como modelo, como motivo sem adornos, um mapa, um esqueleto sem a cobertura de carne. Contudo, a imaginação fértil, as crenças complexas, os sentimentos apaixonados e as motivações poderosas vinculam-se a essa estrutura e completam seu caráter. (p. 35)

Identificamos como tema central a luta por encontrar seu lugar, papel e identidade no mundo e vive-lo plenamente, mesmo que isso implique dificuldades e sofrimento. A partir dessa unidade central, de modo rizomático, a identidade foi discutida cenicamente a partir das relações corpo-psique através das contribuições da teoria junguiana para o tema, assim como a relação da identidade do sujeito com o social.

A cena deveria comportar ao mesmo tempo em uma camada a história de São Sebastião e em outra a mitologia pessoal do performer. Trabalhamos então em uma camada racional, consciente e em uma camada instintiva e inconsciente,

por que o inconsciente apresenta a estrutura de uma mitologia privada. Pode-se ir mais longe ainda e afirmar que não somente o inconsciente é "mitológico", mas também que alguns de seus conteúdos estão carregados de valores cósmicos; em outros termos, que eles refletem as modalidades, os processos e os destinos da vida e da matéria vivente. Pode-se mesmo dizer que o único contato real do homem moderno com a sacralidade cósmica é efetuado pelo inconsciente, quer se trate de seus sonhos e de sua vida imaginária, quer das criações que surgem do inconsciente (poesia, jogos, espetáculos, etc.) (ELIADE, Mircea. 2016, p.73). 
Para Jung, os mitos são antes de qualquer outra coisa, manifestações da essência da alma. A alma inconsciente do homem primitivo é impelida a assimilar toda a experiência sensorial a acontecimentos anímicos.

\begin{abstract}
Para o primitivo não basta ver o Sol nascer e declinar; esta observação exterior deve corresponder - para ele - a um acontecimento anímico, isto é, o Sol deve representar em sua trajetória o destino de um deus ou herói que, no fundo, habita unicamente a alma do homem. Todos os acontecimentos mítologizados da natureza, tais como o verão e o inverno, as fases da lua, as estações chuvosas, etc, não são de modo algum alegorias destas, experiências objetivas, mas sim, expressões simbólicas do drama interno e inconsciente da alma, que a consciência humana consegue apreender através de projeção - isto é, espelhadas nos fenômenos da natureza (2000, p. 18).
\end{abstract}

A divisão que fazemos dessas duas camadas se dá com o intuito de ilustrar o processo, pois uma forma de pensamento é inseparável da outra no homem contemporâneo. O indivíduo por vezes mergulha em fantasias em um processo de pensamento circular e em alguns momentos, a adaptação ao mundo externa exige o pensamento linear (BOECHAT, 2008). Durante o processo, o trabalho se fez concreto no que Walter Boechat chama de zona elipsóide de pensamento, que seria a junção do pensamento circular e linear que gera uma via simbólica de pensamento.

\title{
O corpo mitopoético
}

A mitologia e o inconsciente pessoal e coletivo são universos fugidios, que ao mesmo tempo em que nos compõem, nos escapam. Contudo, podendo o espírito ser qualquer coisa, a terra é algo definido. Para Jung, "manter-se fiel a terra significa manter-se em um relacionamento constante com o corpo" (apud ZIMMERMANN, p. 11). A carne, a pele, o corpo é então uma porta de acesso a psique, a essas tessituras oníricas, afinal, "corpo e psique são dois aspectos do ser vivo, e isso é tudo que sabemos. Assim, prefiro afirmar que os dois elementos agem simultaneamente, de forma milagrosa, e é melhor deixarmos as coisas assim, pois não podemos imaginá-las juntas" (JUNG, 2011, p. 49).

Durante as vivências e investigações cênicas, pensamos e experienciamos o corpo entregue a dança, afinal "as danças consistem na reiteração de todos os acontecimentos míticos" (ELIADE, 1996, p. 91), com o intuito de facilitar o acesso 
ao inconsciente e se abrir a experiências arquetípicas (ALMEIDA, 2011) e processos relacionados à memória a partir de estados alterados de consciência.

Esse estado alterado de consciência acontece sempre que imagens emocionalmente carregadas se ligam à experiência ou a atividade corporal e pode provocar mudanças tanto no nível biológico quanto no nível psicológico, que não poderiam ser produzidas pela vontade ou reflexão. (WURZBA, 2011, p. 93)

O intuito de acessar essas imagens emocionalmente carregadas se dá ao fato dos mitos pessoais, segundo Feinstein e Krippner (1997), guardarem íntima relação com os sentimentos profundos e se refletirem em imagens oriundas das profundezas do ser. Contudo, o acesso a esse material não foi efetivado com tanta facilidade.

Quando abordamos inicialmente o trabalho o inconsciente, ele é uma noz dura, difícil de quebrar. Não conseguimos penetrar nele, não compreendemos nossos sonhos e assim por diante; temos que quebrar a casca para compreender as imagens e somos repelidos até descobrir que elas contêm uma mensagem, algo que alimenta (FRANZ, 2000, p.137).

Por muito tempo durante o processo nos deparamos com barreiras psicocorpóreas que impediam a eclosão dessas imagens e energias arquetípicas e da "fluída realização dos impulsos interiores" (FLASZEN, 2010, p. 88). Um dos motivos dessa dificuldade era um exagerado virtuosismo técnico. Baseando-se nos princípios propostos por Grotowski, modificamos a perspectiva em sala de ensaio do "como fazer" para entender o que impedia a realização sincera da ação.

Todos os sistemas conscientes no campo da atuação fazem a pergunta: "como fazer isto?". E é assim que deveria ser. Um método é a consciência desse "como fazer". Acredito que se deva perguntar isto a si mesmo ao menos uma vez na vida; mas, assim que entrar nos detalhes, não se deve mais fazer essa pergunta pois, no momento em que ela é formulada, começa-se a criar estereótipos e clichês. Então a pergunta a se fazer é: "o que não devo fazer?" (Grotowski, 2011, p. 163).

Com o tempo, o corpo dançante já não mais reproduzia uma série harmoniosa de movimentos ritmados, mas se tornou um canal por onde escoavam, como correnteza, imagens que até então não faziam parte ou não haviam aparecido no repertório de movimentos do ator, carregadas de energia emocional e com memórias que se materializavam no instante das experiências e permaneciam como rastros por alguns encontros. Segundo Elizabeth Zimmermann, "o movimento é uma matriz de projeção, sobre a qual, até certo ponto, a experiência interior pode 
efetuar-se como imagem". Ainda segundo a autora, essas imagens e estados emocionais que eclodem da movimentação do bailarino "possibilitam um confronto com a constelação arquetípica ou com a constelação de complexos de uma pessoa" (2011, p. 163).

Jolande Jacobi (foi docente do instituto C. G. Jung em Zurique e uma das colaboradoras do Jung) delineia os arquétipos como a representação de uma "condição estrutural da psique, que, sob certa constelação (de natureza interna e externa), é capaz de produzir os mesmos padrões" (2016, p. 59). Segundo a autora, eles constituem um sistema axial potencial e são pré-formados no inconsciente, não possuindo existência material e se manifesta no mundo externo após ser iluminado, consolidado e vestido pela consciência.

Com o contínuo trabalho corporal buscando a eliminação de bloqueios psicofísicos e o estado corpóreo onde há uma dilatação dos sentidos e o rebaixamento da consciência havíamos aberto canais para que esses conteúdos de natureza profunda tomassem corpo materializando assim imagens, emoções, e memórias por uma via simbólica.

\section{A busca do Corpo de Sebast - ião - ian}

Durante a pesquisa de construção do corpo cênico optamos por não realizar a mimese corpórea do São Sebastião, mas por buscar um conjunto de energias,

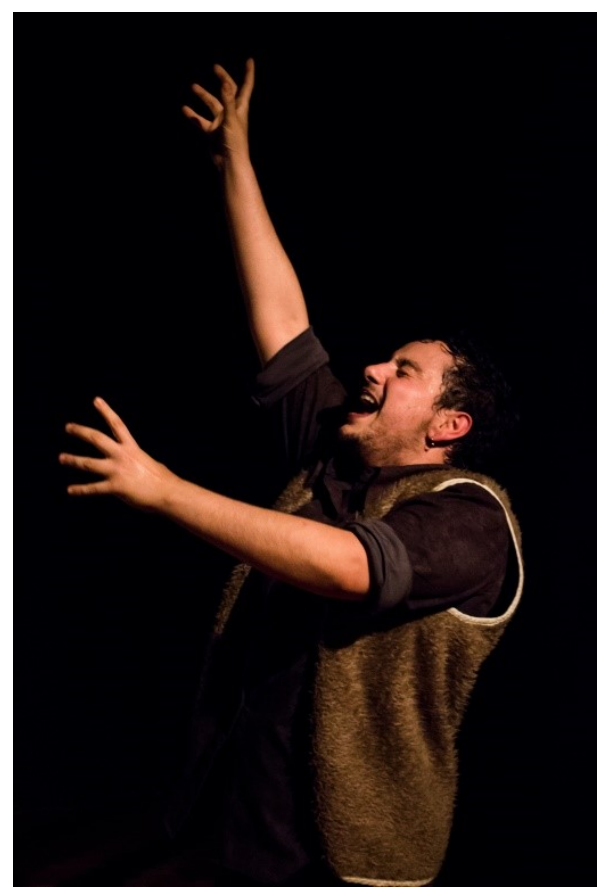

Foto: Danilo Foizer 
afetos e estados de ânimo que correspondessem à imagem que possuíamos em nossa mente desse santo e que fossem compatíveis com as características do performer. Buscamos uma existência, uma experiência, presentificada no entre Sebastião-Sebastian.

Apoiamo-nos na crença apontada por Artaud de que o ator deve ser um atleta afetivo trabalhando assim a materialidade fluídica da alma e sua relação com o organismo. "Saber que existe uma saída corporal para a alma permite alcançar essa alma num sentido inverso" (2006, p. 154). Trabalhando a alma, alcançamos então o mito encarnado, a partir da proposição junguiana na qual "a alma contém todas as imagens das quais surgiram os mitos" (JUNG, 2000, p. 18)

Nos escritos de Jung, a psique é por vezes tratada como alma. Ela media as relações do ego com o inconsciente, sendo condição indispensável para toda relação com o mundo. "A alma é o ponto de partida de todas as experiências humanas, e todos os conhecimentos que adquirimos acabam por levar a ela" (2012, p. 71).

"A alma humana vive unida ao corpo, numa unidade indissolúvel, por isto só artificialmente é que se pode separar a psicologia dos pressupostos básicos da biologia" (2012, p. 60). No trabalho com movimentação expressiva, "o que é abstrato, o mundo do espírito, o mundo dos arquétipos, dos grandes valores, deve descer para encontrar a alma, a psique e se expressar no mundo concreto, no corpo, nas nossas atitudes" (ALMEIDA, 2011, p. 22).

A partir de uma série de vivências dançantes e ritualizadas realizadas a partir de provocações e perguntas que tinham como objetivo gerar a fricção do sujeito Sebastian com o Sebastião mitológico eclodiram uma correnteza de imagens associadas a emoções, memórias e sentimentos. Memórias de caráter individual e coletivo gravadas no corpo

Michael Pollak sobre os elementos constitutivos da memória individual e coletiva:

Em primeiro lugar, são os acontecimentos vividos pessoalmente. Em segundo lugar, são os acontecimentos que eu chamaria de "vividos por tabela", ou seja, acontecimentos vividos pelo grupo ou pela coletividade à 
qual a pessoa se sente pertencer. São acontecimentos dos quais a pessoa nem sempre participou mas que, no imaginário, tomaram tamanho relevo que, no fim das contas, é quase impossível que ela consiga saber se participou ou não. Se formos mais longe, a esses acontecimentos vividos por tabela vêm se juntar todos os eventos que não se situam dentro do espaço-tempo de uma pessoa ou de um grupo. É perfeitamente possível que, por meio da socialização política, ou da socialização histórica, ocorra um fenômeno de projeção ou de identificação com determinado passado, tão forte que podemos falar numa memória quase que herdada (1992, p. 201)

Para Halbwachs (2003), o indivíduo carrega dois tipos de memória, a individual e a coletiva. Isso pode ser relacionado a essa ideia de memória herdada, ainda que em muitos momentos se origine em comportamentos diferentes e opostos:

Por um lado, suas lembranças teriam lugar no contexto de sua personalidade ou de sua vida pessoal. [...] Por outro lado, em certos momentos, ele seria capaz de se comportar simplesmente como um membro de um grupo que contribui para evocar e manter lembranças impessoais, na medida em que estas interessam ao grupo (p. 71).

A partir disso, no instante em que a memória coletiva interpenetra a memória individual do sujeito, esta confirma lembranças, preenche lacunas, se desloca, por vezes confunde-se, e segue seu curso, ao assimilar e incorporar progressivamente essas lembranças. "Para evocar seu próprio passado, em geral a pessoa precisa recorrer às lembranças de outras, e se transporta a pontos de referência que existem fora de si, determinados pela sociedade" (HALBWACHS, 2003, p.72). O funcionamento da memória individual, por sua vez, toma emprestado de seu ambiente palavras e ideias, ainda que individualmente seja possível lembrar daquilo que vimos, sentimos, falamos e pensamos num determinado tempo.

Ao pensar o ato de recriar memórias, Assman (2011) reflete sobre a importância da presença das imagens que surgem na memória principalmente em regiões não alcançadas pelo processamento verbal: "imagens e textos adaptam-se de modos diferentes à paisagem do inconsciente; há uma fronteira líquida entre imagem e sonho; a imagem é elevada à visão e provida de vida própria" (p. 245). Observamos aí variados suportes à memória como constituição de uma narrativa expressiva. A memória do corpo, por exemplo, ao buscar sua própria narrativa no inconsciente, surge de um armazenamento de longo tempo sob pressão e violência, e muitas vezes de inscrições culturais nesse corpo. Diz Aleida Assman: 
O etnólogo Pierre Castres, utilizando ritos de iniciação como exemplo, confirmou de modo muito impressionante essa relação entre dor e memória. Na verdade ele faz valer a ideia de que uma memória corporal se fixa, mesmo depois do alívio da dor, em traços e cicatrizes. 'Depois da iniciação, quando já ficou esquecida a dor, ainda resta algo, um resíduo irreversível, os vestígios que a faca ou a pedra deixam no corpo, as cicatrizes das feridas recebidas. Um homem iniciado é um homem marcado [...]. As marcas impedem o esquecimento, o próprio corpo traz em si as marcas da memória, o corpo é memória' (ASSMAN, 2011, p. 264).

Ao darmos ênfase às recordações biográficas individuais, observamos assim a fusão entre recordação e afeto que acontece, segundo a autora, de forma indissolúvel: "a memória afetiva baseia-se em uma experiência psicofísica que escapa não apenas à verificação externa, como também à revisão própria" (p. 271). Os fatos, sentimentos e suas relações com o passado distinguiram-se entre verdade objetiva e veracidade subjetiva, e permitiram estruturar novas narrativas a partir das matrizes memoriais.

No processo de criação do espetáculo, era necessário, para o nosso intuito cênico, criar um fio condutor para as experiências desse corpo, criar uma rede de acontecimentos, uma dramaturgia, mas antes de tudo era necessário conseguir reviver essas experiências, reabrir os canais para que a memória se atualizasse e se criasse, se recriasse constantemente. Encontramos na poética dos elementos materiais proposta por Gaston Bachelard uma possibilidade de caminho para a realização de um trabalho energético e a manutenção da vida dos movimentos, partituras e materiais cênicos até então levantados, a partir do que ele denomina memória material.

Por efeito achamos possível estabelecer, no reino da imaginação, uma lei dos quatro elementos que classifica as diversas imaginações materiais conforme elas se associam ao fogo, ao ar, à água ou à terra. E, se é verdade, como acreditamos, que toda poética deve receber componentes por fracos que sejam - de essência material, é ainda essa classificação pelos elementos materiais fundamentais que deve aliar mais fortemente as almas poéticas. Para que um devaneio tenha prosseguimento com bastante constância para resultar em uma obra escrita, para que não seja simplesmente a disponibilidade de uma obra fugaz, é preciso que ele encontre sua matéria, é preciso que um elemento material lhe dê sua própria substância, sua própria regra, sua poética específica (BACHELARD, 1989, p.3-4).

Mergulhamos no trabalho com os elementos. Passamos a trabalhar diariamente em uma pesquisa energética com base nas distintas qualidades que éramos capazes de aferir aos elementos da natureza (seus níveis de profundidade, 
sua agitação, sua força, velocidade, suas origens - lágrimas, nascentes, mares, brisas, furacões, incêndios etc.) e em seguida acrescíamos ao exercício alguma memória anteriormente trabalhada, alguma cena rascunhada, alguma imagem corpórea. Imbricamos camadas naquele corpo em movimento, camadas sensíveis, simbólicas, semióticas.

Quando se encontrou a raiz substancial da qualidade poética, quando se encontrou realmente a matéria do adjetivo, a matéria sobre a qual trabalhava a imaginação material, todas as metáforas bem enraizadas desenvolvem por si mesmas (BACHELARD, 1989, p.34).

A partir dos elementos materiais conseguimos induzir os tipos de emoção ou memória que deveriam ser materializadas naquele corpo no decorrer da experiência da cena-ritual. Conseguimos trabalhar indiretamente com uma constelação arquetípica que acreditamos corresponder ao mito guia, pois, segundo Jung (2008), os arquétipos que

aparecem na experiência prática: são ao mesmo tempo imagem e emoção; e só podemos nos aferir a arquétipos quando esses dois aspectos se apresentam simultaneamente. Quando existe apenas a imagem, ela equivale a uma descrição de pouca importância. Mas quando carregada de emoção, a imagem ganha numinosidade (ou energia psíquica) e torna-se dinâmica, acarretando várias consequências (p.122).

A cena, contudo, para existir, precisa do diálogo constante entre interior e exterior, entre o universo das percepções do performer e o mundo concreto. Fezse necessário traçar percursos para que esse diálogo interno/externo pudesse ser efetivado. Partimos então para a estrutura do ritual-cênico.

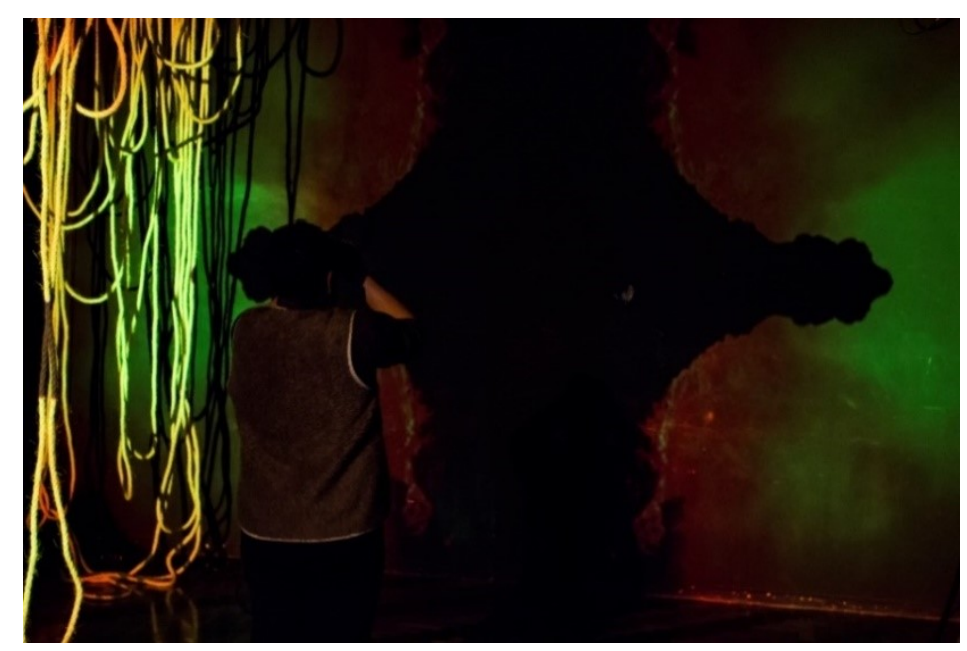




\title{
A estruturação de um ritual de sacrifício
}

O processo de criação que percorremos nos colocou na fronteira entre a mitologia pessoal e toda sua extensão e o mito de São Sebastião. Dentro dos estudos realizados sobre o tema da identidade, chegamos à percepção de que várias pessoas se sacrificam diariamente real e simbolicamente em suas lutas pelo direito de existir. São Sebastião se sacrificou em função de suas crenças religiosas. Tiramos então o sacrifício como elo relacional desses dois universos e partimos dele para a estruturação do rito cênico. O espetáculo seria construído como um ritual de sacrifício.

Fazemos uma alusão ao processo de individuação para explicar as relações da psique nesse momento de criação:

\begin{abstract}
Quando se consegue formular o conteúdo inconsciente e entender o sentido da formulação, surge a questão de saber como o ego se comporta diante dessa situação. Tem, assim, início a confrontação entre o ego e o inconsciente. Está é a segunda e a mais importante etapa do procedimento, isto é, a aproximação dos opostos da qual resulta o aparecimento de um terceiro elemento que é a função transcendente. Neste estágio, a condução do processo já não está mais com o inconsciente, mas com o ego (JUNG, 2012, p. 33-34).
\end{abstract}

A consciência elabora e seleciona os símbolos que se criam a partir das formas arquetípicas fornecidas pelo inconsciente.

\begin{abstract}
Apenas o símbolo consegue ligar o que há de mais diferente a uma impressão total unificada [...]. Palavras tornam o infinito finito, símbolos transportam o espírito para além dos limites do finito, do devir, para o reino do mundo do ser infinito. Eles despertam pressentimentos, são sinais do inexprimível, são inesgotáveis como este (BACHOFEN apud JACOBI, 2016, p. 95).
\end{abstract}

No trabalho em questão, utilizamos a estrutura básica de um rito fundamental de sacrifício, conforme proposta por Marcel Mauss e Henri Hubert, pois por um lado, conforme apontado, seria uma possibilidade de encontro de todas as mitologias trabalhadas e por outro, cria vetores de sentido imbricando mais uma possível camada de leitura da obra. Isso culminaria no que Patrice Pavis (2005) aponta, para a análise da encenação, como processo de vetorização, ou seja, um meio simultaneamente metodológico, mnemotécnico e dramatúrgico de estabelecer ramais de signos: "Ela (a vetorização) consiste em associar e conectar signos que 
são pegos em ramais no interior dos quais cada signo só tem sentido na dinâmica que o liga aos outros" (p. 13).

Os autores Mauss e Hubert apontam a necessidade de ritos que introduzam os agentes envolvidos em um mundo sagrado. Esses ritos constituem o que eles chamam de a entrada no sacrifício.

\begin{abstract}
O sacrifício é um ato religioso que só pode se efetuar num meio religioso e por intermédio de agentes essencialmente religiosos. Ora, antes da cerimônia, em geral, nem o sacrificante, nem o sacrificador, nem o lugar, nem os instrumentos, nem a vítima têm esse caráter no grau que convém. Assim, a primeira fase do sacrifício tem por objeto conferir-lhe esse caráter. Eles são profanos, e é preciso que mudem de estado (MAUSS \& HUBERT, 2005, p. 26).
\end{abstract}

Essa mudança de estado proposta pelo autor reflete de duas maneiras distintas em nosso trabalho. A primeira diz respeito ao processo de pesquisa corpórea, na qual o performer parte de um trabalho com exageros estilísticos em um percurso de eliminação de elementos que geram resistência aos impulsos psíquicos. O ator abandona seu estado de cortesão para ir a caminho do ator sagrado (GROTOWSKI, 2011).

A segunda maneira na qual a proposta de entrada no sacrifício reverberou em nosso processo foi na construção das primeiras cenas do espetáculo. Nessas cenas a estrutura dramática ritual dava conta do encontro simbólico de Sebastian e Sebastião mediados pelo nascimento, fato esse que ganha mais uma camada de sentido tendo em vista que o performer nasceu no dia de São Sebastião.

"Inicia-se toda uma série de cerimônias simbólicas que progressivamente irão despojar o sacrificante do ser temporal que ele era para fazê-lo renascer sob espécies inteiramente novas" (MAUSS \& HUBERT, 2005, p. 26). Nessa fase, o sujeito ritual (transitante) carrega consigo atributos do passado e do estado futuro. (GENNEP, 2011). Para a construção desse momento, revisitamos as experiências rituais e mantivemos as que foram mais significativas, trabalhando nos ritmos da mesma e inserindo camadas simbólicas e semióticas a partir de processos de edição e também a partir da inserção de mídias. 


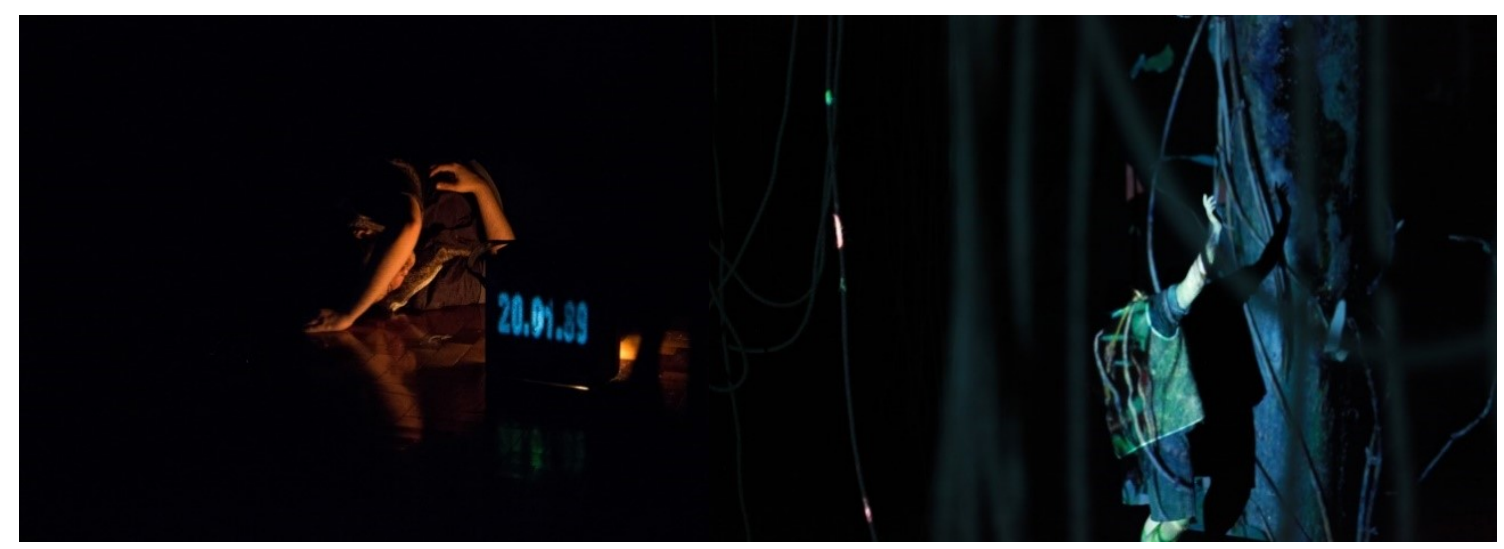

Fotos: Danilo Foizer

As mídias foram o único elemento espetacular que não se pretenderam enquanto mecanismos potencializadores do trabalho do performer, mas sim como meio de ampliar a experiência simbólica do público. Visto que o símbolo

\begin{abstract}
pode até mesmo tornar o divino, de certo modo, visível [...]. Com força irresistível, ele atrai a pessoa observadora para si [...] e, necessariamente, como o próprio espírito do mundo, captura nossa alma. Nele se agita uma fonte exuberante de ideias vivas; e o que a razão, unida ao entendimento, busca em sucessivas inferências, ele o obtém aqui, na aliança com o sentido, totalmente e de uma só vez (CREUTZER apud JACOBI, 2016 p. 95-96).
\end{abstract}

Os símbolos, as imagens e vídeos projetados na parede, na cenografia ou no corpo do ator tiveram como mote os estados internos desse corpo em uma relação metafórica com a natureza. Uma árvore que é cortada por um machado e "sangra", sague que escorre no corpo do ator, a natureza do performer que é devastada. Uma árvore com dezenas de metros de altura toda flechada, líquens que aos poucos preenchem todo o espaço no qual desaparece o performer. As imagens, que ao mesmo tempo trazem o peso da destruição interna do performer, carregam a simbologia de crescimento e desenvolvimento que a árvore propõe nos eixos horizontal e vertical, assim como o aspecto vegetativo inconsciente e as raízes do mundo instintivo (ALMEIDA, 2011).

A última fase que construímos cenicamente é a imediatamente anterior ao ato sacrificial,

o sacrifício é precedido de uma purificação mais ou menos longa. Ela consiste principalmente em aspersões de água lustral e em abluções, e às vezes, o sacrificante deve jejuar e se purgar. Deve vestir roupas limpas ou mesmo roupas especiais que lhe conferem um início de santidade. O ritual 
romano geralmente prescrevia o uso de véu, sinal de separação e, portanto de consagração (MAUSS \& HUBERT, 2005, p.28).

"Nós nos beijaríamos. Nós nos amaríamos. Eu sou o oceano". São as frases ditas enquanto o ator Sebastian Habib retira suas roupas para o banho sacrificial e revela o corpo de um artista transgênero, ampliando assim os significados presentes em cada gesto e palavra do espetáculo, assim como em cada imagem que o compôs Após o banho, enquanto se retira do espaço cênico, vídeos de agressões a travestis e transexuais tomam conta do espaço se fundindo a imagens do Santo, o mito se atualiza para discutir questões sociais emergentes. (criar aqui uma citação sobre mito e contemporaneidade). $\mathrm{O}$ ato sacrificial é realizado na relação dos rastros deixados pelo performer, de sua presença estabelecida pela ausência e dos corpos que virtualmente eram assassinados.

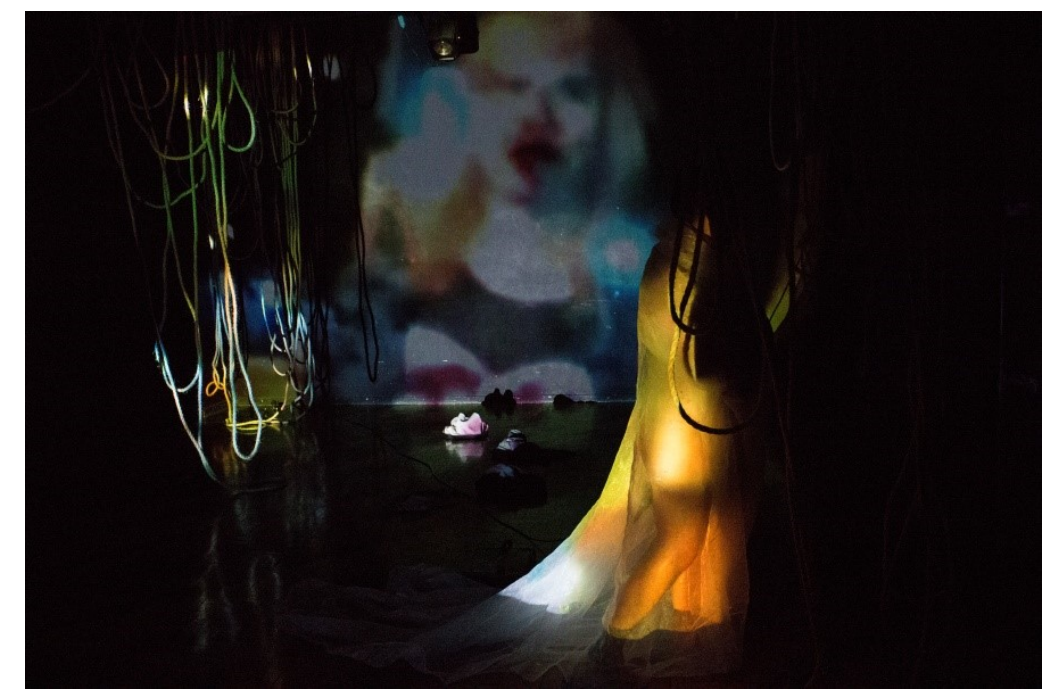

Foto: Danilo Foizer

\section{Experiência mitopoética}

Campbell aponta os mitos como "pistas para as potencialidades espirituais da vida humana" (2011, p. 6). Segundo o autor,

o que estamos procurando é uma experiência de estar vivos, de modo que nossas experiências de vida, no plano puramente físico, tenham ressonância no interior de nosso ser e de nossa realidade mais íntimos, de modo que realmente sintamos o enlevo de estar vivos. É disso que se trata, afinal, e é o que essas pistas nos ajudam a procurar, dentro de nós mesmos (2011, p.5). 
No decorrer do processo, percebemos que há momentos em que a experiência mítica realmente se instaura, que a ressonância da experiência de vida ocorre. Eliade diz "que de uma maneira ou de outra, "vive-se" o mito, no sentido de que se é impregnado pelo poder do sagrado e exaltante dos eventos rememorados ou reatualizados" (2016, p.22). Abaixo, o relato do performer após um ensaio geral no qual entendemos que a experiência mística se instaurou no corpo, tempo e espaço.

\begin{abstract}
Começou com a sensação de habitar um grande útero. Apagaram-se momentaneamente todas as conexões com o concreto. Havia apenas ecos e rastros de pensamentos e memórias completamente desordenados e caóticos, como que mergulhados no líquido uterino, dentro de uma placenta. Com acesso restrito, eu não conseguia mais acessá-los quando desejava. Nessa grande luta caí, amorteci e o cansaço me tomou. Deligaram-se várias válvulas. Senti um escuro momentâneo. Quando me levantei a luz me cegava. Não sabia mais o que estava fazendo, onde estava, quem era. A partir de então eu senti que eram esses mesmos ecos e rastros que me acessavam, me tomavam, desordenadamente e no tempo deles. Tornei-me um filtro. Já não ouvia ruídos vindos da rua e do público presente. Abriu-se uma fenda na realidade. Vivi em uma realidade outra, na qual as noções dos movimentos partiam de uma outra lógica temporal. A noção de começo e fim deixou de existir e eu deixei de seguir objetivamente a estrutura de ações proposta. Ao longo do processo, senti que deixei de habitar meu corpo, um corpo unificado e centralizado, e me conectei a diversos outros corpos diferentes e não presentes na realidade concreta. Foi como dissipar e descentralizar minhas percepções. Havia um corpo material - meus músculos e ossos - realizando ações e movimentos, mas ele era guiado por diversos outros corpos. Em determinado momento senti uma ruptura ainda maior. Foi como se da dissipação na minha percepção eu conseguisse acessar algo ainda maior, uma consciência superior. Já não havia mais interno e externo. Eu era tudo e todos naquela sala. No momento final, em que era realizado um banho, o contato da água em meu corpo me trouxe um longo, profundo e desesperado choro. E eu entendi tudo. Era o momento de sair do grande útero. Meu renascimento.
\end{abstract}

Essa experiência ocorreu após aproximadamente nove meses de processo contínuo. Vários canais foram abertos para que esse momento no performer teve sua história pessoal restaurada por meio do mito e o mito foi restaurado por meio da história, da experiência e do corpo do performer pudesse ocorrer. Grotowski, sobre o trabalho de ator, aponta "que é apenas uma questão de doar-se. [...] Mergulhar em si mesmo, transe, excesso e a própria disciplina formal, tudo isso pode se realizar, desde que haja doação total, humildemente e sem defesa. Esse ato culmina num clímax. Ele traz alívio" (2011, p.29).

As sensações extracotidianas de tempo e espaço indicam além da influência de um estado emocional, o rebaixamento da consciência, conforme Jung: 
o observador pode facilmente ser influenciado por um estado emocional que altera o espaço e o tempo no sentido de uma contração. Todo estado emocional opera uma mudança na consciência, mudança que $P$. Janet chamou de abaissement du niveau mental (baixa do nível mental, isto é, há um certo estreitamento da consciência, acompanhado de um fortalecimento simultâneo do inconsciente, facilmente reconhecível por qualquer leigo, particularmente nos casos de efeitos muito fortes. $\mathrm{O}$ tônus do inconsciente como que se eleva, criando facilmente um declive em que o inconsciente pode fluir para a consciência. A consciência cai, então, sob a influência de impulsos e de conteúdos instintivos inconscientes (JUNG, 2014, p.40).

O resultado cênico a partir dessa pesquisa mitopoética nos forneceu "uma estrutura que permite às imagens que refletem a mitologia variada da cultura misturar-se às impressões diversas da experiência diárias" (FEINSTEIN \&KRIPNER, 1997, p.36) do performer gerando assim um conteúdo de fundo universal. No que diz respeito ao trabalho de ator, assim como a estética resultante, se mostrou um percurso de trabalho que coloca a identidade cultura do performer em primeiro lugar em detrimento de uma técnica especifica e o obriga a um trabalho de auto mergulho profundo numa busca de si mesmo e concordando com Campbell, nos possibilita a experiência de estar vivos.

\section{REFERÊNCIAS}

ALMEIDA, Vera L. P. Movimento Expressivo: a integração fisiopsíquica através do movimento. In ZIMMERMANN, Elizabeth (Org.). Corpo e Individuação. Petrópolis: Vozes, 2011.

ARTAUD, Antonin. O Teatro de seu Duplo. São Paulo: Martins Fontes, 2006.

ASSMAN, Aleida. Espaços da recordação: formas e transformações da memória cultural. Campinas: Editora da Unicamp, 2011.

BACHELARD, Gaston. A água e o sonho: ensaio sobre a imaginação da matéria. São Paulo: Martins Fontes, 1989.

BOECHAT, Walter. A mitopoese da psique: mito e individuação. Petrópolis: Vozes, 2008.

CAMPBELL, Joseph. MOYERS, B. O Poder do mito. São Paulo: Palas. Athena, 2011.

ELIADE, Mircea. Mito e realidade. São Paulo: Perspectiva, 2016.

FEINSTEIN, David \& KRIPPNER, Stanley. Mitologia pessoal: a psicologia evolutiva do self. São Paulo: Cultrix, 1997. 
FLASZEN, Ludwik; POLASTRELLI, Carla (org.) O teatro laboratório de Jerzy Grotowski 1959 - 1969. São Paulo: Perspectiva: SESC; Pontedera, IT: Fondazione Pontedera Teatro, 2010.

FRANZ, Marie-Louise von. O gato: um conto de redenção feminina. São Paulo: Paulus, 2000.

GENNEP, Arnold Van. Os ritos de passagem. Petrópolis: Vozes, 2011.

GROTOWSKI, Jerzy. Para um teatro pobre. Brasília: Teatro Caleidoscópio \& Dulcina, 2011.

HALBWACHS, Maurice. A memória coletiva. São Paulo: Centauro, 2003.

JACOBI, Jolande. Complexo, arquétipo e símbolo: na psicologia de C. G. Jung. Petrópolis: Vozes, 2016.

JUNG, Carl G. A natureza da psique. Petrópolis: Vozes, 2012.

A vida simbólica. Petrópolis: Vozes, 2011

O Homem e seus Símbolos. Rio de Janeiro: Nova Fronteira, 2008

Os arquétipos e o inconsciente coletivo. Petrópolis: Vozes, 2000.

Sincronicidade. Petrópolis: Vozes, 2014.

MAUS, Marcel \& HUBERT, Henri. Sobre o sacrifício. São Paulo: Cosac Naify, 2005.

PAVIS, Patrice. A análise dos espetáculos: teatro, mímica, dança, dança-teatro, cinema. São Paulo: Perspectiva, 2005.

POLLAK, Michael. Memória e identidade social. In: Estudos Históricos. Rio de Janeiro, vol. 5.n. 10,. 1992, p. 200-212

WURZBA, Lilian. A dança da alma: a dança e o sagrado, um gesto no caminho da individuação. In ZIMMERMANN, Elizabeth (Org.). Corpo e Individuação. Petrópolis: Vozes, 2011

ZIMMERMANN, Elizabeth. Individuação em contato com o corpo simbólico. In ZIMMERMANN, Elizabeth (org.). Corpo e Individuação. Petrópolis: Vozes, 2011. 